\title{
Co vše skrývá krevní obraz
}

\author{
Harazim M. ${ }^{1,3}$, Chvojka J. ${ }^{2,3}$ \\ 'Jednotka intenzivní péče, Interní gastroenterologická klinika Fakultní nemocnice Brno \\ ${ }^{2}$ Jednotka intenzivní péče, I. interní klinika Fakultní nemocnice Plzeň \\ ${ }^{3}$ Lékařská fakulta v Plzni Univerzity Karlovy v Praze
}

\section{Úvod}

V posledních 10 letech bylo identifikováno více než 170 markerů sepse [1], at' už s funkcí diagnostickou, prognostickou či k monitoraci efektu terapeutických intervencí. Výzkumné týmy směřují čím dále více do hlubin pacientova genomu, intenzivně se zabývají proteomikou. Přitom už dnes máme na dosah velmi užitečné, levné a jednoduché markery z rutinních vyšetření, které mohou stratifikovat riziko nemocných již $\checkmark$ době príchodu do nemocnice a které velmi často zůstávají opomíjeny. Takovou schopnost mají některé ukazatele vyplývající z diferenciálního rozpočtu bílé krevní řady. V tomto sdělení se budeme snažit krátce približit 3 nejvíce probádané - poměr neutrofilů a lymfocytů (NLR - neutrophil/lymphocyte ratio), poměr monocytů k lymfocytům (MLR - monocyte-to lymphocyte ratio) a poměr destiček k lymfocytům (PLR - platelet-to-neutrophil ratio).

\section{NLR}

Poměr neutrofilů a lymfocytů je již relativně dobře zmapovaným markerem napříč všemi obory akutní medicíny. Pravděpodobně odráží míru endogenního stresu mediovanou především hladinou endogenních katecholaminu, cytokinů a kortizolu. $V$ rámci fyziologické odpovědi na stresový inzult (infekční i neinfekční) dochází k relativně rychlému ( $<6$ h po inzultu [2]) vzestupu hladiny neutrofilů a současně poklesu lymfocytární řady jako odrazu aktivace buněčné imunity. Jedná se tedy o marker nespecifický, přesto velmi hodnotný ve stratifikaci rizika dalšího průběhu stonání či efektu zavedených léčebných opatření. $\checkmark$ prípadě úvodní evaluace septického nemocného dosahuje výpovědní hodnoty mortalitního rizika minimálně srovnatelné s hladinou laktátu, zároveň překonává zavedené ukazatele inflamace - CRP i prokalcitonin [3]. Jeho užitečnost byla prokázána i v evaluaci peroperačního rizika, diagnostice bakteremie či stratifikace rizika akutní pankreatitidy, kde rovněž překonává etablované skórovací systémy [4]. Svou prognostickou úlohu plní např. i u plicní embolizace [5] či prì triage COVID+ nemocných [6], u kterých je vysoká NLR hodnota jasně spojena s nepř́znivým průběhem a trajektorií spojenou s časnou potřebou umělé plicní ventilace. Rovněž je možné pomocí NLR sledovat úspěch terapeutických intervencí a jeho pokles koreluje s efektivitou naší léčby. Zajímavou možností je i využití NLR jako parametru pro fenotypizaci našich nemocných v klinických studiích.

Potenciálně problematické a zároveň diagnosticky velmi cenné je stanovení NLR u nemocného s adrenální insuficiencí. V tomto prípadě je NLR nezvýšené, což v prípadě významnější oběhové deteriorace a event. i eozinofilie je jasnou nápovědou ke stanovení hladiny kortizolu. Falešně vyšší hodnoty NLR detekujeme po podání exogenního kortikoidu.

Jasné cut-off hodnoty NLR ještě nejsou zcela přesně ustáleny. Dle současných poznatků odpovídají přibližně uvedené grafice (obr. 1) [7].

Obr. 1. Referenčni hodnoty NLR s návrhem obecné interpretace hladin stresu korelující s klinickým výstupem (adaptováno z https:/lemcrit.org) pulmcrit/n/r/)

\begin{tabular}{|ccccc|}
\hline & & & & \\
& & & & \\
$1-3$ & $4-5$ & $6-9$ & $9-18$ & $>18$ \\
normální & šedá & lehký & mírný & těžký \\
hodnota & zóna & stres & stres & stres \\
\hline
\end{tabular}

\section{MLR, PLR}

Na rozdíl od NLR nejsou poměry monocytů k lymfocytům či destiček k lymfocytům zaštítěny takovým množstvím klinických studií a jejich klinická role nebyla dosud plně ustanovena. Jako slibný marker byl PLR popsán v diagnostice kolorektálního karcinomu [8], v monitorování aktivity choroby u nemocných se SLE [9], prognóze nemalobuněčného karcinomu plic [10] či akutní končetinové ischemie [11].

MLR má svou diagnostickou hodnotu v časné detekci virových nákaz nejen u infekcí SARS-Cov-2 [12], kde byl v poslední době opakovaně evaluován, jako prognostický marker schopný stratifikovat nemocné s nepríznivým průběhem však opakovaně selhává [13].

\section{Závěr}

Diferenciální rozpočet bílé krevní řady, který je rutinní součástí vyšetření našich pacientů, v sobě ukrývá řadu dalších užitečných parametrů. Ač žádný z nich nenaplňuje definici ideálního biomarkeru, svou jednodu- 
chostí a rychlou stanovitelností představují velmi užitečné pomocníky nejen $v$ diagnostice, ale i léčbě řady akutních stavů či v perioperační péči. Zejména NLR umožňuje velmi rychle stratifikovat mortalitní riziko a event. potřebu pobytu na intenzivním lůžku nejen u septických nemocných. Určitě by neměl uniknout naší pozornosti a zcela jistě má potenciál se stát rutinní součástí diagnosticko-terapeutického procesu nejen v prostředí intenzivní péče.

\section{K zapamatování}

- Pokud vyhodnocujete diferenciální krevní obraz bílé řady, zajímejte se i o odvozené parametry (především poměr neutrofilů a lymfocytů - NLR)

- NLR je nespecifickým markerem stresu organismu a aktivace buněčné imunitní odpovědi.

- NLR umožňuje stratifikaci rizika nemocných dřive nežjiné ukazatele.

PROHLÁŠENÍ AUTORŮ: Prohlášení o původnosti: Práce je původní a nebyla publikována ani není zaslána k recenznímu řízení do jiného média. Střet zájmů: Autoři prohlašují, že nemají střet zájmů v souvislosti s tématem práce. Podíl autorů: Všichni autoři rukopis četli, souhlasí s jeho zněním a zasláním do redakce časopisu Anesteziologie a intenzivní medicína. MH text rukopisu, JCH korekce. Financování: Podpořeno MZ ČR - RVO (FNBr, 65269705). Podpořeno Programem rozvoje vědních oborů Univerzity Karlovy (Progres - projekt Q39) a Národním programem udržitelnosti I (NPU I) č. LO1503 poskytovaným Ministerstvem školství, mládeže a tělovýchovy.

\section{LITERATURA}

1. Pierrakos C, Velissaris D, Bisdorff M, Marshall JC, Vincent J-L. Biomarkers of sepsis: time for a reappraisal. Critical Care. 2020; 24(1): 1-15.

2. Zahorec R. Ratio of neutrophil to lymphocyte counts--rapid and simple parameter of systemic inflammation and stress in critically ill. Bratisl Lek Listy. 2001; 102(1): 5-14.

3. Ljungström L, Pernestig A-K, Jacobsson G, Andersson R, Usener B, Tilevik D. Diagnos tic accuracy of procalcitonin, neutrophil-lymphocyte count ratio, C-reactive protein, and lactate in patients with suspected bacterial sepsis. PloS one. 2017; 12(7): e0181704. 4. Jeon TJ, Park JY. Clinical significance of the neutrophil-lymphocyte ratio as an early predictive marker for adverse outcomes in patients with acute pancreatitis. World journal of gastroenterology. 2017; 23(21): 3883

5. Karataş MB, İpek G, Onuk T, Güngör B, Durmuş G, Çanga Y, et al. Assessment of prognostic value of neutrophil to lymphocyte ratio and platelet to lymphocyte ratio in patients with pulmonary embolism. Acta Cardiologica Sinica. 2016; 32(3): 313.

6. Bastug A, Bodur H, Erdogan S, Gokcinar D, Kazancioglu S, Kosovali BD, et al. Clinical and laboratory features of COVID-19: Predictors of severe prognosis. International immunopharmacology. 2020; 88: 106950

7. Farkas J. PulmCrit: Neutrophil-Lymphocyte Ratio (NLR): Free upgrade to your WBC 2019 Dostupné z: https://emcrit.org/pulmcrit/nlr/.
8. Zhang J, Zhang H-Y, Li J, Shao X-Y, Zhang C-X. The elevated NLR, PLR and PLT may predict the prognosis of patients with colorectal cancer: a systematic review and meta-analysis. Oncotarget. 2017; 8(40): 68837

9. Wu Y, Chen Y, Yang X, Chen L, Yang Y. Neutrophil-to-lymphocyte ratio (NLR) and platelet-to-lymphocyte ratio (PLR) were associated with disease activity in patients with systemic lupus erythematosus. International immunopharmacology. 2016; 36: 94-99.

10. Phan TT, Ho TT, Nguyen HT, Tran TB, Nguyen ST. The prognostic impact of neutrophi to lymphocyte ratio in advanced non-small cell lung cancer patients treated with EGFR TKI. Int J Gen Med. 2018; 11: 423-430.

11. Gary T, Pichler M, Belaj K, Hafner F, Gerger A, Froehlich H, et al. Platelet-to-lymphocyte ratio: a novel marker for critical limb ischemia in peripheral arterial occlusive disease patients. PloS one. 2013; 8(7): e67688.

12. Merekoulias G, Alexopoulos EC, Belezos T, Panagiotopoulou E, Jelastopulu DM. Lymphocyte to monocyte ratio as a screening tool for influenza. PLoS Curr. 2010; 2: Rrn1154. 13. Peng J, Qi D, Yuan G, Deng X, Mei Y, Feng L, et al. Diagnostic value of peripheral hematologic markers for coronavirus disease 2019 (COVID-19): A multicenter, cross-sectional study. J Clin Lab Anal. 2020: e23475. 